\title{
Intraspecific variation and population structure of the Velvetbean Caterpillar, Anticarsia gemmatalis Hübner, 1818 (Insecta: Lepidoptera: Noctuidae)
}

\author{
Daniel R. Sosa-Gómez \\ Embrapa Soybean, Londrina, PR, Brazil
}

\begin{abstract}
The velvetbean caterpillar (VBC), Anticarsia gemmatalis Hübner, 1818 (Insecta: Lepidoptera: Noctuidae), is one of the most important New World soybean agro-ecosystems pests, occurring from $40^{\circ} \mathrm{N}$ in the USA to $39^{\circ} \mathrm{S}$ in Argentina. Information on the migration patterns of the VBC moth may be important for managing the resistance of VBC populations to insecticides or plants carrying the Bacillus thuringiensis insecticide genes, especially since sedentary populations have a higher potential to became resistant than migratory populations. We studied intraspecific variations of geographically distinct VBC populations in order to determine the genetic distance between them and to assess the variability of VBC populations from near the city of Londrina (Paraná (PR) state, Brazil). Samples of the VBC were obtained from sites near the following towns or cities: Marianna and Quincy (Florida, USA); La Virginia (Tucumán province, Argentina); Londrina (PR), Passo Fundo (Rio Grande do Sul, Brazil) and Planaltina (Goiás, Brazil). The VBC samples were used to construct a genetic similarity matrix based on random amplified polymorphic DNA (RAPD) allele frequencies, the cotton leafworm, Alabama argillacea, Hübner 1823 (Insecta: Lepidoptera: Noctuidae), being used as an outgroup. Interestingly, despite the great distance (about 6,500 km) between Planaltina and Quincy some of the specimens from the Quincy population clustered in a group genetically close to the Planaltina populations. Larvae collected on peanuts in Marianna and on soybean in Quincy, $70 \mathrm{~km}$ apart, appeared genetically similar. The population from Planaltina was the most heterogeneous (polymorphism $=85.6 \%$; heterozygosity $=0.1505$ ). The Argentinean VBC population was entirely different from the Brazilian populations. The genetic similarities found between individuals from geographically distant populations and effective migration rate values $(2.0566>N m<15.2618)$ indicate that migration occurs.
\end{abstract}

Key words: molecular marker, RAPD, gene flow, soybean pest, population structure.

Received: February 5, 2003; Accepted: February 20, 2004.

\section{Introduction}

The velvetbean caterpillar (VBC), Anticarsia gemmatalis Hübner, 1818 (Insecta: Lepidoptera: Noctuidae), is one of the most important key pests in New World soybean agro-ecosystems, being widely distributed and causing losses in yield in all areas were soybean is cultivated. Larvae of the A. gemmatalis moth occur from approximately $40^{\circ} \mathrm{N}$ in the USA (Puttler and Long, 1980) to south of Buenos Aires ( $39^{\circ} \mathrm{S}$ ) in Argentina (Sosa-Gómez, D.R. personal observation). The moths can have a more northerly distribution (Puttler and Long, 1980) than the larvae but there is as yet no evidence that the adults have a more southerly distribution than the larvae. The extent of genetic variation of $A$. gemmatalis depends on various factors, including gene flow between geographical populations and on the elapsed time since the populations

Send correspondence to Daniel R. Sosa-Gómez. Embrapa Soja, Caixa Postal 231, 86001-970 Londrina, PR, Brazil. E-mail: drsg@cnpso.embrapa.br. separated if mechanisms of reproductive isolation are an effective barrier.

In Brazil, little is known as to whether or not geographically separated $A$. gemmatalis populations are genetically discrete or if their genotypes overlap. Since soybean and alternative host plants can be found throughout the year it is possible that local sedentary velvetbean caterpillar populations occur, although it is also possible that this moth could behave in an intermediate manner with part of the population being resident and part migratory, i.e. it is a non-calculated migrating species as suggested by Pashley (1985). Although adult A. gemmatalis is thought to be a strong flier (Johnson and Mason, 1985) it is not know to what extent specific biotypes or related genotypes are distributed in a specific geographical region. This could be important in managing populations resistant to insecticides or transgenic plants carrying insecticide genes because populations which are sedentary or have a reduced rate of susceptible immigrants have a higher potential to became resistant (Georghiou and Taylor, 1986). Another important 
aspect of this insect biology is the differential response to pheromones by different geographical populations. For example synthetic pheromones developed for $A$. gemmatalis populations from the USA did not elicit consistent responses in Brazilian A. gemmatalis populations (Mafra, Leandro Isca Technologies personal communication). If populations of $A$. gemmatalis with different genotypes behave in different ways an understanding of population structure and gene flow along with recognition of the biotypes present in the populations using diagnostic markers may be useful in managing these populations.

Random amplified polymorphic DNA (RAPD) techniques have been useful in tracking the origin of introduced insect pests (Williams et al., 1994) and in differentiate ecotypes (Pornkulwat et al., 1998). In the study described in this paper the intraspecific variation of RAPD alleles was used to determine the genetic distance between geographically distinct $A$. gemmatalis populations.

\section{Material and Methods}

\section{Insect samples}

Specimens of A. gemmatalis, commonly known as the velvetbean caterpillar (VBC), were obtained from sites near the following towns or cities: Marianna and Quincy (Florida, USA); La Virginia (Tucumán province, Argentina); Londrina (PR), Passo Fundo (Rio Grande do Sul, Brazil) and Planaltina (Goiás, Brazil). The samples of $A$. gemmatalis larvae were collected in peanut fields in Marianna and soybean fields for all the other sites. Cotton leafworm, Alabama argillacea Hübner, 1823 (Insecta:
Lepidoptera: Noctuidae), specimens collected in cotton fields near Londrina-PR were used as an outgroup (Table 1).

All larvae were kept under laboratory conditions until pupation in order to avoid contamination with parasitoids and entomopathogens, the larvae being sexed by waiting for them to pupate and examining the morphology of the pupa. In most cases we used 26 pupae from each geographical population (13 males and 13 females from Londrina and Planaltina; 15 males and 11 females from Florida and Passo Fundo) except for the $A$. gemmatalis samples from Argentina and the $A$. argillacea samples from Londrina, where each sample consisted of 3 male and 3 female pupae. When the larvae had pupated the pupa were stored at $-15^{\circ} \mathrm{C}$ until DNA extraction. Distances between sampling sites were calculated with the software available in the world wide web (http://www.wcrl.ars.usda.gov/cec/java/lat-long. htm).

\section{DNA extraction}

The DNA was extracted from whole pupae according to a modified Cheung et al., (1993) protocol. Each pupae was homogenized in a microcentrifuge tube using a pestle and $600 \mu \mathrm{L}$ of extraction buffer, $150 \mu \mathrm{L}$ of $5 \%$ sarcosyl was added and the mixture incubated for $5 \mathrm{~min}$ at $65^{\circ} \mathrm{C}$ before adding $7.5 \mu \mathrm{L}$ of a $10 \mathrm{mg} / \mathrm{mL}$ proteinase $\mathrm{K}$ solution and incubating at $65{ }^{\circ} \mathrm{C}$ for $60 \mathrm{~min}$. The mixture was then cooled at room temperature for $5 \mathrm{~min}$ and centrifuged at $14,000 \mathrm{rpm}$ for $15 \mathrm{~min}$. The upper phase $(400 \mu \mathrm{L})$ was transferred to another microcentrifuge tube and an equal volume of chloroform/isoamyl alcohol (24:1) added. After

Table 1 - Collection data for the velvetbean caterpillar (Anticarsia gemmatalis) and the cotton leafworm (Alabama argillacea) samples.

\begin{tabular}{|c|c|c|c|c|}
\hline Accession number & Sex & Collection site* & Crop & Sampling Date \\
\hline \multicolumn{5}{|c|}{ Anticarsia gemmatalis } \\
\hline LDA1 to LDA13 & Female & Londrina, Paraná, Brazil & Soybean & February and March, 2002 \\
\hline LDA14 to LDA26 & Male & Londrina, Paraná, Brazil & Soybean & February and March, 2002 \\
\hline BRA1 to BRA13 & Female & Planaltina, Goiás, Brazil & Soybean & January 27,2000 \\
\hline BRA14 to BRA26 & Male & Planaltina, Goiás, Brazil & Soybean & January 27,2000 \\
\hline PF1 to PF11 & Female & Passo Fundo, Rio Grande do Sul, Brazil & Soybean & February 18,2000 \\
\hline PF12 to PF26 & Male & Passo Fundo, Rio Grande do Sul, Brazil & Soybean & February 18,2000 \\
\hline FL1 to FL9 & Female & Quincy, Florida, USA & Soybean & September 8, 1999 \\
\hline FL12 to FL23 & Male & Quincy, Florida, USA & Soybean & September 8, 1999 \\
\hline FL10 and FL11 & Female & Marianna, Florida, USA & Peanut & September 8, 1999 \\
\hline FL24 to FL26 & Male & Marianna, Florida, USA & Peanut & September 8, 1999 \\
\hline ARG1 to ARG3 & Female & La Virginia, Tucumán, Argentina & Soybean & February 18,2000 \\
\hline ARG4 to ARG6 & Male & La Virginia, Tucumán, Argentina & Soybean & February 28, 2000 \\
\hline \multicolumn{5}{|l|}{ Alabama argillacea } \\
\hline ALA1 to ALA3 & Female & Londrina, Paraná, Brazil & Cotton & January 26,2000 \\
\hline ALA4 to ALA6 & Male & Londrina, Paraná, Brazil & Cotton & January 26,2000 \\
\hline
\end{tabular}

*Town, state or province, country. 
gentle homogenization the samples were centrifuged at $14,000 \mathrm{rpm}$ for $15 \mathrm{~min}$ after which the aqueous phase was transferred to a new microcentrifuge tube and the chloroform/isoamyl alcohol procedure repeated. The DNA in the aqueous layer was precipitated by the addition of 2 volumes of cold $100 \%$ isopropanol plus $45 \%$ of the final volume of $10 \mathrm{M}$ ammonium acetate. The samples were kept overnight at $4{ }^{\circ} \mathrm{C}$ and then centrifuged at $14,000 \mathrm{rpm}$ for $15 \mathrm{~min}$ and the upper phase discarded, the DNA pellet being washed with about $400 \mu \mathrm{L}$ of $70 \%$ ethanol and the tubes recentrifuged at 14,000 rpm for 5 min after which the upper phase was discarded and the tubes containing precipitated DNA inverted to dry the DNA samples. After $2 \mathrm{~h}$ the pellets were resuspended in $300 \mu \mathrm{L}$ of Tris/EDTA buffer $(10 \mathrm{mM}$ Tris- $\mathrm{HCl}(\mathrm{pH} 8.0)$ and $1 \mathrm{mM}$ EDTA) containing a final concentration of $10 \mu \mathrm{g} / \mathrm{mL}$ of RNAse and then incubated at $37^{\circ} \mathrm{C}$ for $30 \mathrm{~min}$. The amount of DNA was estimated with a fluorometer (Brunk et al., 1979) and the integrity of the DNA verified by agarose gel $(0.8 \%, \mathrm{w} / \mathrm{v})$ electrophoresis using 1X TBE (pH 8.0) buffer (0.089 M Tris base, $0.089 \mathrm{M}$ Boric acid and $0.002 \mathrm{M}$ EDTA) and $120 \mathrm{~V}$. The gels were stained with $10 \mathrm{mg} / \mathrm{mL}$ ethidium bromide and the DNA fragments visualized with a UV transilluminator and photographed using black and white Polaroid 667 ISSO 3000 film. The template DNA was diluted to $3 \mathrm{ng} / \mu \mathrm{L}$ for RAPD processing.

\section{RAPD Methodology}

We screened 67 different 10 base oligonucleotide primers (Operon Technologies. Alameda, CA, USA) using pooled samples of DNA from each population and selected 15 primers which amplified all the DNA samples and produced scorable bands that could be used to identify polymorphisms between the different individuals. Amplification was carried out in a total volume of $25 \mu \mathrm{L}$ containing approximately $9 \mathrm{ng}$ of template DNA, $0.4 \mu \mathrm{M}$ of one of the primers, $2.4 \mathrm{mM}$ of $\mathrm{MgCl}_{2}, 0.1 \mathrm{mM}$ of each dNTP, 1 unit of Taq polymerase enzyme (Gibco BRE), $2.5 \mu \mathrm{L}$ of $10 \mathrm{X}$ buffer and sufficient Milli Q sterile water to complete the final volume. Independent control reactions without genomic DNA were conducted for each primer. Primers that produced spurious products were not used in the analysis. The polymerase chain reaction (PCR) was performed using a GeneAmp-9600 thermal cycler (Perkin Elmer) programmed for 45 cycles of $94{ }^{\circ} \mathrm{C}$ for $15 \mathrm{~s}, 35^{\circ} \mathrm{C}$ for $30 \mathrm{~s}$ and $72{ }^{\circ} \mathrm{C}$ for $1 \mathrm{~min}$ with a final extension at $72^{\circ} \mathrm{C}$ for $7 \mathrm{~min}$. The RAPD products were separated from $25 \mu \mathrm{L}$ of the reacted mixture by electrophoresis in a gel containing $1 \%$ synergel and $0.6 \%$ agarose using 1 XTBE buffer at $120 \mathrm{~V}$, lambda phage DNA cut with EcoR I, Hind III and BamH I restriction enzymes being used as molecular weight markers. Gels were stained with $4.5 \mu \mathrm{L}$ of $10 \mathrm{mg} / \mathrm{mL}$ ethidium bromide solution and photographed under UV light using ISSO 3000 black and white Polaroid 667 film.

\section{Data analysis}

The photographs of gels generated from the RAPD analysis were scanned but only distinct bands were included in the binary matrix. Each sample was scored for the presence (score 1) or the absence (score 0 ) of each distinct band. The data matrix was obtained using the image analysis module of the Bionumerics program (Applied Maths, 1998). We used the numerical taxonomy and multivariate analysis system (NTSYS-pc, version 1.80) program (Rohlf, 1992) to construct the genetic distance matrices with the SIMGEND program and the dendrograms with the SAHN program using the unweighted pair-group method with arithmetic means (UPGMA). To determine which component accounted for most of the variation we performed principal coordinate analysis based on dissimilarity measures using the SIMGEND, DCENTER and EIGEN procedures of the NTSYS-pc program.

The RAPD markers generated from the $A$. gemmatalis DNA were also analyzed assuming that RAPD alleles segregate following Mendelian laws, homologous DNA fragments co-migrate, different loci segregate independently and that populations are in Hardy Weinberg equilibrium. The percentage of polymorphic loci, heterozygosity and average effective gene flow between regions $(\mathrm{Nm})$ were calculated using version 1.32 of the Popgene program (Yeh and Boyle, 1997), Nm also being estimated for each pair of populations based on Nei's coefficient of genetic differentiation $\left(G_{\mathrm{ST}}\right)$ (Nei 1973). The $A$. argillacea RAPD were excluded from the analysis.

\section{Results}

The primer sequences that produced scorable $A$. gemmatalis polymorphisms are listed in Table 2. Gel electrophoresis of the different sets of RAPD reaction products resulted in 465 polymorphic bands, the number of bands for each population ranging from 17 to 46 with a mean of 31 (Table 2). The size of the amplification products ranged 500 to $2500 \mathrm{bp}$ and no monomorphic bands occurred (data not shown). The RAPD profile generated with primer OPA-01 is given in Figure 1 as an example of the profiles produced.

The UPGMA dendrogram (Figure 2) constructed from the similarity matrix based on the RAPD marker allele frequencies obtained using Nei's genetic distance (Nei, 1972 ) shows geographically distinct $A$. gemmatalis populations. The Argentinean populations (cluster A) had very tightly clustered maximum similarity indices and were clearly distant from the populations from the other regions. Caterpillars collected in Londrina clustered in one group (cluster F) with males and females being separated into two subgroups, although one sample (LDA15) that was sexed as a male clustered in the female group. The populations from Planaltina showed more genetic variability than the other populations (Table 3 ), the maximum dissimilarity be- 
Table 2 - Primers that gave reliable amplification products of Anticarsia gemmatalis genomic DNA.

\begin{tabular}{lcc}
\hline Primer & \multicolumn{1}{c}{ Sequence } & Band number \\
\hline OPA-01 & 5'-CAGGCCCTTC-3' & 31 \\
OPA-05 & 5'-AGGGGTCTTG-3' & 17 \\
OPA-08 & 5'-GTGACGTAGG-3' & 23 \\
OPA-16 & 5'-AGCCAGCGAA-3' & 29 \\
OPA-17 & 5'-GACCGCTTGT-3' & 23 \\
OPB-18 & 5'-CCACAGCAGT-3' & 19 \\
OPC-09 & 5'-CTCACCGTCC-3' & 22 \\
OPH-14 & 5'-ACCAGGTTGG-3' & 41 \\
OPK-17 & 5'-CCCAGCTGTG-3' & 17 \\
OPL-11 & 5'-ACGATGAGCC-3' & 41 \\
OPN-01 & 5'-CTCACGTTGG-3' & 40 \\
OPN-02 & 5'-ACCAGGGGCA-3' & 37 \\
OPO-03 & 5'-CTGTTGCTAC-3' & 42 \\
OPO-18 & 5'-CTCGCTATCC-3' & 46 \\
OPX-15 & 5'-CAGACAAGCC-3' & 37 \\
\hline
\end{tabular}

tween individuals from the same geographical population being observed in the Planaltina samples (BRA24, BRA25 and BRA26 in the dendrogram). The Planaltina females were linked to the Passo Fundo population (cluster E) while most of the Planaltina male pupae were in cluster B which was linked to the Florida population (cluster C), the biological significance of this link being unknown. With few exceptions, pupae of the same sex clustered together in the Planaltina, Londrina and Passo Fundo populations. Although similar results have been obtained for the neotropical brown stink bug, Euschistus heros (Fabricius 1798) (Sosa-Gómez et al., 2004) and for Triatoma brasiliensis (Neiva, 1911), sex-clustering was not reported by Borges et al., (2000). A. gemmatalis larvae collected from peanut fields in Marianna, and on soybean in Quincy, $(70 \mathrm{~km}$ apart) were similar. One specimen collected in Passo Fundo was close related to Londrina and Planaltina individuals.
The RAPD analysis was able to discriminate individuals from the same geographical population, the maximum level of similarity obtained occurring between two female A. gemmatalis from Argentina. The Argentinean population also showed the minimum genetic distance, with $24 \%$ polymorphic loci and the lowest heterozygosity of all the populations studied (Table 3 ). The $A$. argillacea outgroup, also with a small number of specimens, also showed low polymorphism and heterozygosity.

Principal coordinate analysis was conducted to detect interpopulation relationships, examination of the eigen vectors revealing that specific DNA amplified fragments are useful, but not especially important, in discriminating between populations. The correlation of each variable with the percentage variance was partially explainable by the three principal components, the variation being 31.8, 43.5 and $54.77 \%$ respectively for the three first components.

The overall genetic diversity represented by the Gst value was 0.1402 , suggesting that variation between the five $A$. gemmatalis populations was low (14\%) compared to the variation within each population (86\%). The overall migration index $(\mathrm{Nm}=3.067)$ indicated that migratory events occur. The highest genetic differentiation values obtained were those for the pairwise comparisons of the Argentinean samples (Table 4).

The same primers used for $A$. gemmatalis were also useful in evaluating polymorphism in A. argillace $a$ and discriminating between individual $A$. argillacea specimens. The A. argillacea sample showed similar levels of intraspecific polymorphism and heterozygosity to that observed in the A. gemmatalis samples from Argentina.

\section{Discussion}

Black et al., (1992) has suggested that RAPD can be used to measure clonal diversity even in insects such as aphids which reproduce asexually but show extensive polymorphism and Lou et al., (1998) has reported variation in RAPD within and between geographic populations of the wheat stem sawfly (Cephus cinctus Norton, 1872), so it is

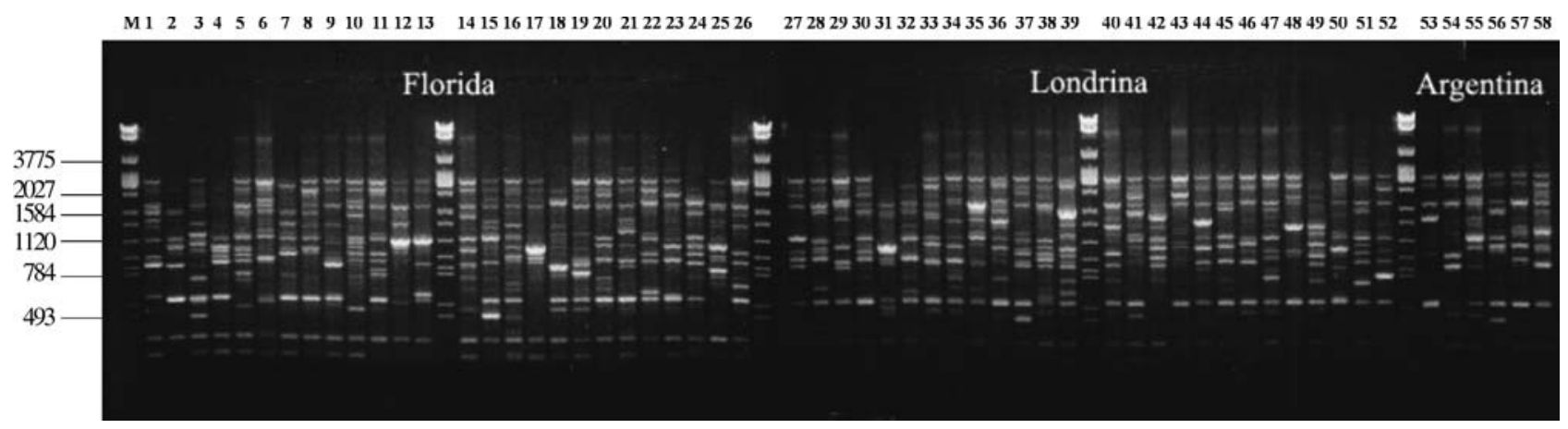

Figure 1 - Intraspecific variation in the OPA-01 primer RAPD-PCR amplification products of Anticarsia gemmatalis genomic DNA. Phage $\lambda$ DNA cut with EcoR I, Hind III and BamH I restriction enzymes was used as the molecular weight marker (M). Lanes 1-11: Florida females; 12-26: Florida males; 27-39: Londrina females; 40-52: Londrina males; 53-55: La Virginia females; 56-58: La Virginia males. 


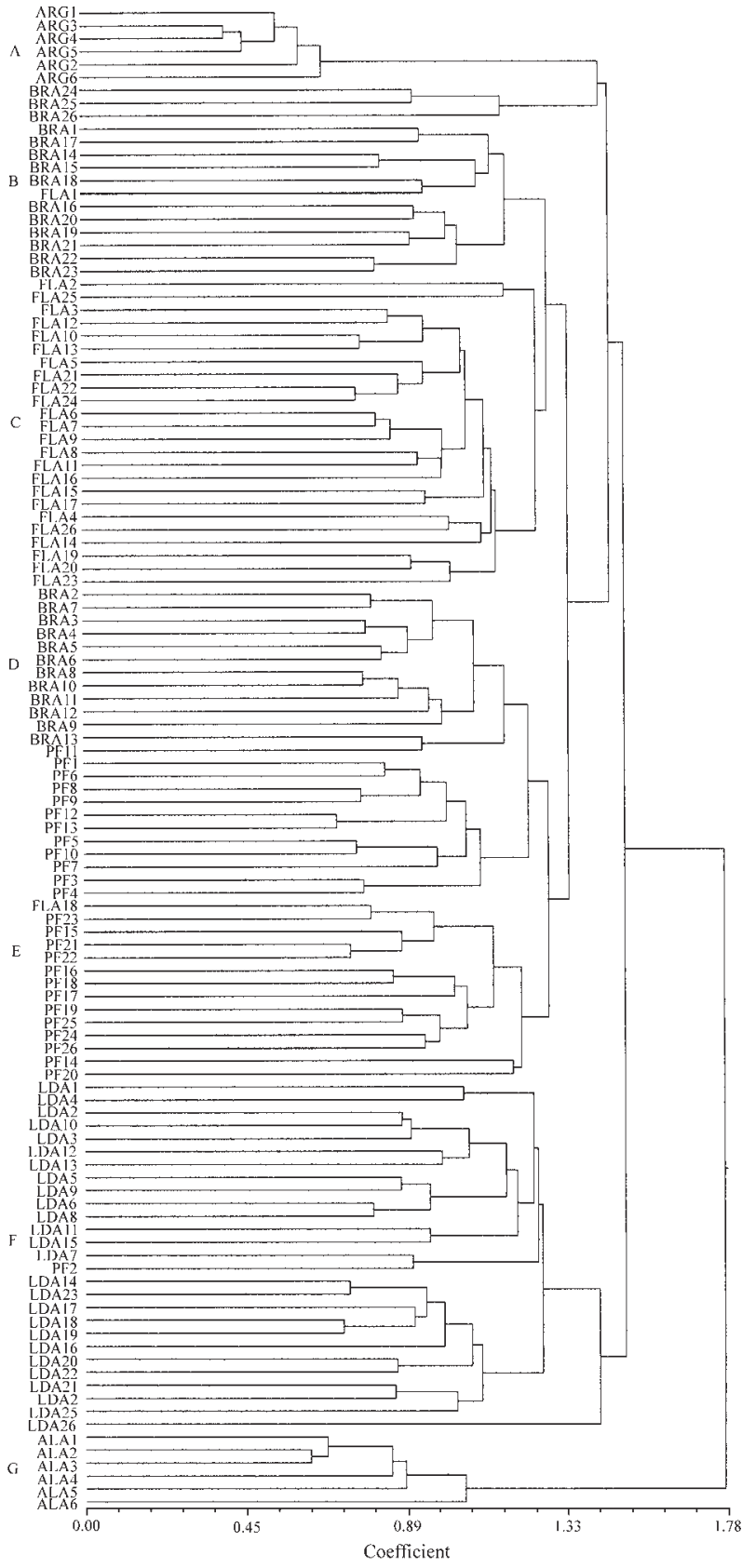

Figure 2 - Unweighted pair-group method with arithmetic means (UPGMA) dendrogram for six geographically separated Anticarsia gemmatalis populations and one Alabama argillacea outgroup population based on estimated Nei's genetic distance (Nei 1972) calculated using the allelic frequencies of RAPD markers. A total of 116 pupae were sampled.

not surprising that in an outbred insect such as $A$. gemmatalis every insect was genetically unique.

During the DNA extraction protocol care was taken to minimize contamination with DNA from other organisms such as parasitoids but the presence of foreign DNA could not be absolutely ruled out due to high prevalence of pathogens (e.g. fungi) in A. gemmatalis populations, an aspect that has rarely been considered in intra and interspecific variability studies. The $A$. gemmatalis population collected
Table 3 - Genetic variability indices (polymorphism and heterozygosity) of Anticarsia gemmatalis and Alabama argillacea populations.

\begin{tabular}{lcc}
\hline Species and origin & Polymorphism (\%) & Heterozygosity $(\mathrm{H})^{*}$ \\
\hline Anticarsia gemmatalis & & \\
Florida, USA & 83.2 & 0.1461 \\
Planaltina, Brazil & 85.6 & 0.1505 \\
Londrina, Brazil & 78.5 & 0.1244 \\
Passo Fundo, Brazil & 79.3 & 0.1357 \\
La Virginia, Argentina & 24.3 & 0.0744 \\
\hline Alabama argillacea & & \\
Londrina, Brazil & 33.0 & 0.0867 \\
\hline
\end{tabular}

*Nei’s gene diversity value (Nei, 1973).

in Argentina produced a very tight cluster (cluster A) revealing homogeneity, possibly due to the narrow timewindow sampled (i.e. the small number of individuals from a single sampling date), and was genetically distant from the populations from Brazil and the USA.

More similarity was observed between individual larva collected in Planaltina (Brazil, cluster B) and Florida (USA, cluster C) than between the Argentinean and Brazilian populations, suggesting that gene flow may be occurring between Brazil and the USA. In spite of the fact that the shortest distance between Planaltina and Quincy is about 6,500 $\mathrm{km}$ the Quincy larvae clustered close to the Planaltina males, the Planaltina females being linked to the Passo Fundo larvae. Similar results have been obtained by Pashley (1985) who found that, although Tapachula (Mexico) and Campina Grande (Brazil) are $6,700 \mathrm{~km}$ apart, $A$. argillacea populations from these sites were practically identical genetically.

Pashley (1985) suggested that Louisiana and other south-central states are colonized each summer by migrant A. gemmatalis travailing north through Middle America. Because the Louisiana populations are more similar to the South Carolina populations it seems that the Mexican, Honduran, Costa Rican, Louisiana and South Carolina populations are different to the Florida population and that the Florida populations do not contribute to summer outbreaks further north. It is possible that a similar process could have been occurring in the $A$. gemmatalis populations described in this paper and that the populations from Londrina, Passo Fundo and Argentinean may be composed in their majority by non-migratory or permanently resident genotypes.

In the study described in this paper the percent of polymorphic loci and the level of heterozygosity were in the range observed for other Lepidoptera (Pashley et al., 1985). The highest levels of heterogeneity between individuals from the same population were observed in the Planaltina population, with, as shown in Figure 2, individual Planaltina larva clustering with the Florida population (clusters B and C) and the Passo Fundo population (clusters $\mathrm{D}$ and $\mathrm{E}$ ). 
Table 4 - Pairwise comparison of Nei's gene differentiation coefficient (Gst; below the diagonal) and estimated gene flow (Nm; above the diagonal) for Anticarsia gemmatalis populations.

\begin{tabular}{lccccc}
\hline & \multicolumn{5}{c}{$N m$} \\
\cline { 2 - 6 } Gst & Florida & Planaltina & Londrina & Passo Fundo & La Virginia \\
\hline Florida, USA & - & 15.2618 & 8.8555 & 11.3234 & 2.5064 \\
Planaltina, Brazil & 0.0317 & - & 10.6372 & 13.5286 & 2.6901 \\
Londrina, Brazil & 0.0534 & 0.0449 & - & 8.8436 & 2.0566 \\
Passo Fundo, Brazil & 0.0423 & 0.0356 & 0.0535 & - & 2.2134 \\
La Virginia, Argentina & 0.1663 & 0.1567 & 0.1956 & 0.1843 & - \\
\hline
\end{tabular}

The Londrina samples were collected during the same growing season between February 10 and March 2, 2000, that provided a larger 'window' increasing the possibility of collecting the offspring of immigrant individuals. Nevertheless, variability in the Londrina population was lower than in the Planaltina population, which was collected in just one day. In fact, the Londrina population grouped in a discrete group with just one larva from Passo Fundo being included in this cluster. In terms of migration that means that the occurrence of local populations persisting over several years is possible, with just a few immigrants arriving and outbreeding with the local population. This scenario is supported by the high $\mathrm{Nm}$ values, ranging from 8.8436 to 15.2618, when the Argentinean population was excluded from the analysis (Table 4). Pashley and Johnson (1986) also found high gene flow between populations from the southern USA and Central America.

Pashley (1986) reported genetic differences between Spodoptera frugiperda samples collected on corn, rice or Bermuda grass, suggesting strain-host related associations. During the research described in the current paper the $A$. gemmatalis larvae collected from soybean in Quincy and peanuts in Marianna (both in Florida) showed no genetic differences, the most divergent and the least diverse population being that from Argentina also showed the highest Gst values (Table 4).

Clusters $\mathrm{G}$ and $\mathrm{A}$ have the same sample size, and a comparison of these two clusters show that the cotton leafworm, A. argillacea, also shows interesting intraspecific variability which can be studied with the same primers as those used for A. gemmatalis. In order to obtain more reliable conclusions a more extensive sampling program is necessary in temperate areas such as Rio Grande do Sul, Uruguay or even Argentina during the warm season in order to verify if $A$. gemmatalis exhibits frequent migration from permanent breeding sites to areas with limiting conditions.

\section{Acknowledgments}

I thank Carlos A. Arrabal Arias, Jose F.F. de Toledo from Embrapa Soja and Carlos Caio Machado for a critical review of the manuscript; Silvana R. Rockenbach Marin Embrapa Soja (Empresa Brasileira de Pesquisa Agropecuá- ria, Brazil) Katiaíres E. Delpin, Edson Hirose and Fernando Costa for their technical assistance; Irineu Lorini (Embrapa Trigo, Brazil); Maria Lucrecia Vera, (Conicet, Tucumán, Argentina) Edison Sujii (Embrapa Recursos Genéticos) and Drion Boucias (University of Florida) for the Anticarsia gemmatalis specimens collected in different regions of Argentina, Brazil and the USA respectively; and Alfredo O.R. de Carvalho (Iapar, Paraná, Brazil) for help with data analysis. This work received financial support from Embrapa Soja and CNPq (Conselho Nacional de Desenvolvimento Científico e Tecnológico). Approved for publication by the editorial board of Embrapa Soja as manuscript $02 / 2003$.

\section{References}

Applied Maths (1998) Bionumerics. The Integral Study of Biological Relationships. Manual. Version 1.01, Kortrijk, Belgium, $154 \mathrm{pp}$.

Borges E, Dujardin JP, Schofield CJ, Romanha AJ and Diotaiuti L (2000) Genetic variability of Triatoma brasiliensis (Hemiptera: Reduviidae) populations. J Med Entomol 37:872-877.

Black IV WC, Teau NMD, Puterka GJ, Nechols JR and Pettorini JM (1992) Use of the random amplified polymorphic DNA polymerase chain reaction (RAPD-PCR) to detect DNA polymorphisms in aphids (Homoptera: Aphididae). Bull Entomol Res 82:151-159.

Brunk CF, Jones KC and James TW (1979) Assay for nanogram quantities of DNA in cellular homogenates. Anal Biochem 92:497-500.

Cheung WY, Hubert N and Landry BS (1993) A simple and rapid DNA microextraction method for plant, animal, and insect suitable for RAPD and other PCR analyses. Technical Tips 3:69-70.

Georghiou GP and Taylor CE (1986) Factors influencing the evolution of resistance. In: National Research Council (ed) Pesticide Resistance: Strategies and Tactics for Management. National Academy Press, Washington, DC pp 157-169.

Johnson SJ and Mason LJ (1985) The noctuidae: A case history. In: MacKenzie DR, Barfield CS, Kennedy GG and Burger RD (eds) The Movement and Dispersal of Agriculturally Important Biotic Agents. Claitors Publ. Baton Rouge, LA pp 421-433.

Lou KF, Weiss MJ, Bruckner PL, Morrill WL, Talbert LE and Martin JM (1998) RAPD variation within and among geo- 
graphic populations of wheat stem sawfly (Cephus cinctus Norton). J Hered 89:329-335.

Nei M (1972) Genetic distance between populations. Am Nat 106:283-292.

Nei M (1973) Analysis of gene diversity in subdivided populations. Proc Nat Acad Sci USA 70:3321-3323.

Pashley DP (1985) The use of population genetics in migration studies: A comparison of three noctuid species. In: MacKenzie DR (ed) The Movement and Dispersal of Agriculturally Important Biotic Agents: An International Conference on the Movement and Dispersal of Biotic Agents. Oct 17-19, 1984 Claitor's Publishing Division, Baton Rouge, LA, USA pp 305-324.

Pashley DP (1986) Host-associated genetic differentiation in fall armyworm (Lepidoptera: Noctuidae): A sibling species complex. Ann Entomol Soc Am 79:898-904.

Pashley DP, Johnson SJ and Sparks NA (1985) Genetic population structure of migratory moths: The fall armyworm (Lepidoptera: Noctuidae). Ann Entomol Soc Am 78:756762.

Pashley DP and Johnson SJ (1986). Genetic population structure of migratory moths: The Velvetbean Caterpillar (Lepidoptera: Noctuidae). Ann Entomol Soc Am 79:26-30.

Pornkulwat S, Skoda SR, Thomas GD and Foster JE (1998) Random amplified polymorphic DNA used to identify genetic variation in ecotypes of the European corn borer (Lepidoptera: Pyralidae). Ann Entomol Soc Amer 91:719725 .

Puttler B and Long SH (1980) The velvetbean caterpillar, Anticarsia gemmatalis (Lepidoptera: Noctuidae), in Missouri. J Kans Entomol Soc 53:437-440.

Rohlf FJ (1992) NTSYS-pc. Numerical Taxonomy and Multivariate Analysis System. Version 1.80.

Sosa-Gómez DR, Delpin KE, Almeida AM and Hirose E (2004) Genetic differentiation among Brazilian populations of Euschistus heros (Fabricius) (Heteroptera: Pentatomidae) based on RAPD analysis. Neotropical Entomology 33:179187.

Williams CL, Goldson SL, Baird DB and Bullock DW (1994) Geographical origin of an introduced insect pest, Listronotus bonariensis (Kuschell), determined by RAPD analysis. Heredity 72:412-419.

Yeh FC and Boyle TBJ (1997) POPGENE Microsoft Windowsbased software for Population genetic analysis. A joint project development by Francis C. Yeh, University of Alberta and Tim Boyle, Center for International Forestry Research, Bogor, Indonesia.

Associate Editor: Louis Bernard Klaczko 